\title{
Identifying the Causes of Sea-level Change
}

\section{Glenn A. Milne ${ }^{1}$, W. Roland Gehrels ${ }^{2}$, Chris W. Hughes ${ }^{3}$ and Mark E. Tamisiea $^{3}$}

1. Dept of Earth Sciences, University of Ottawa, Canada.

2. School of Geography, University of Plymouth, UK.

3. Proudman Oceanographic Laboratory, UK.

\section{Preface}

Global mean sea-level rise has increased from a rate of a few centimetres per century over the past few millennia to a few decimetres per century in the past few decades. This ten fold increase in rate is due to climate change and is dominated by melting of land ice and warming of ocean water. The current warming trend is expected to continue and so global mean sea level will continue to rise. In this article, we review recent advances in our understanding of past sea-level changes on decadal to millennial timescales to consider how well future changes can be constrained. The majority of studies suggest that global mean sea-level rise will most likely be less than $1 \mathrm{~m}$ over the $21^{\text {st }}$ century. Importantly, there will be significant departures from the global mean by several decimetres in many areas. As a consequence, future research should be targeted at better constraining the spatial variability in future changes so that high-risk areas can be identified.

\section{Introduction}

With about 200 million people living within coastal floodplains and 2 million $\mathrm{km}^{2}$ of land and \$1 trillion worth of assets lying less than $1 \mathrm{~m}$ above current sea level, sea-level rise is one of the major socio-economic hazards associated with global warming ${ }^{1}$. The expected rate is, however, extremely uncertain. While the latest IPCC report ${ }^{2}$ suggests a range of 0.18-0.59 m of sea-level rise between 1980-1999 and 2090-2099, it emphasises that the contribution from ice dynamic changes is highly uncertain and provides three "illustrative" scenarios suggesting a possible addition of up to $0.17 \mathrm{~m}$ from this source. Since then, several studies ${ }^{3,4}$ have suggested that a rise larger than $1 \mathrm{~m}$ cannot be ruled out. Sea-level rates of this magnitude (m per century) are not uncommon in reconstructions of past sea-level change using geological evidence and it has recently been suggested that similar rates occurred during the previous interglacial warm period 120,000 years ago ${ }^{5,6}$ when the volume of land ice was similar to that at present.

A "headline" figure of $1 \mathrm{~m}$ during the $21^{\text {st }}$ century represents only the global average sealevel rise. Many different physical processes contribute to sea-level change (see Box 1) and none of these produce a spatially uniform signal. Indeed, one of the few statements that can be made with certainty is that future sea-level change will not be the same everywhere. Thus, the development of regional and local estimates of future sea-level rise - required for effective risk assessment - is one of the primary challenges for the coming 
years $^{2}$. Prediction relies on models, and the veracity of model output is based on verification against historical and geological data.. However, interpretation of these data requires great care in light of the large spatial and temporal variability in sea-level change. In this article we summarise recent progress in understanding the variability in a suite of sea-level related observations at timescales ranging from decades to millennia. We conclude with an estimate of our current ability to predict future sea-level rise and highlight outstanding problems to address in the coming years in order to achieve greater accuracy and confidence in such predictions.

\section{The Satellite Era}

The most comprehensive sea-level observations are the most recent. Since 1992, precise satellite altimeter missions have provided near-global maps of absolute sea level (Box 1) every 10 days, permitting the sea-level trend to be determined for the majority of the ocean area (Figure 1).The measurements highlight the non-uniform nature of the change over more than 14 years. Although the average is around $3 \mathrm{~mm} / \mathrm{yr}$, there are regions exhibiting trends of over $10 \mathrm{~mm} / \mathrm{yr}$ and larger areas (notably the north-eastern Pacific) where sea level has fallen over this period. The small spatial scales of some of these differences also draw attention to the issue of spatial sampling.

Recently, two observing systems that complemented the altimetric data have been put into operation. The first, the Argo network, is a series of autonomous floats that sink and ascend, monitoring temperature and salinity in the top 1-2 km of the ocean. Since 2000, the Argo network has increased to more than 3000 floats. The second, the Gravity Recovery And Climate Experiment (GRACE) satellite mission, launched in 2002, measures the global gravity field every month. Resulting maps can be used to monitor month to month gravity changes which are dominated by the motion of water around the Earth. Together, the Argo and GRACE measurement systems can, in principle, separate out the contributions to sea-level change from changes in ocean water density and changes in ocean mass. In the case of GRACE, it is also possible to determine the transfer of land-based water to the ocean.

Initial comparison of all three data sets ${ }^{7}$ highlighted an inconsistency due to apparent ocean cooling $^{8}$. This has since been identified as a result of differing biases in instruments observing ocean temperature ${ }^{9-12}$, while geodetic constraints from observations of the Earth's dynamic oblateness, confirmed that this apparent cooling was not being offset by a large increase in melting land ice ${ }^{13}$. After applying corrections for these biases, several studies ${ }^{14-16}$ have shown greatly improved consistency, in one case ${ }^{14}$ finding a tightly-closed sea-level budget for interannual and seasonal cycles, but a significant imbalance of over $3 \mathrm{~mm} / \mathrm{yr}$ in the trend. In the second case ${ }^{15}$, a smaller net imbalance of about $1 \mathrm{~mm} / \mathrm{yr}$ was found (this is within the estimated error bars). In the third study ${ }^{16}$ GRACE data were used in two different ways, in one case using a larger geodetic correction over the oceans than in other studies, and in the other using it only to estimate Antarctic and Greenland mass loss, and combining with other datasets to estimate the total mass entering the ocean. These two methods both result in a balance to within a small fraction of one $\mathrm{mm} / \mathrm{yr}$. However, between these three studies, there are 
differences of about $1 \mathrm{~mm} / \mathrm{yr}$ among each of the three sea-level components (altimetry, steric and mass), suggesting that this is the true error bound on trend estimates for these short (4-year) time series. Differences may be partly a result of slightly different time spans chosen and the dominant role of interannual variability over periods of only a few years, but there are also issues with each of the observing systems.

Problems with calibration of the temperature measurements were noted above, but a significant part of the imbalance arises from the incomplete temperature sampling of the ocean, particularly the Southern Ocean ${ }^{14}$, which may be insufficient prior to $2004^{16}$. The development of innovative ways to reduce sampling bias $^{17}$ is important. The GRACE mass estimates suffer from a number of complications that contribute to their uncertainty. Because of the small signal over the oceans, compared to those over land, the analysis must reduce both the sampling of the nearby land signal along the coasts ${ }^{18}$ and the presence of correlated errors in the GRACE solutions ${ }^{19,20}$. In addition, the GRACE mission is insensitive to geocenter motion, i.e. the motion of the Earth's centre of figure relative to the center of mass of the whole Earth (including cryosphere, hydrosphere and atmosphere). Ignoring this contribution can introduce an underestimate of up to $30 \%$ in sea-level rise caused by Greenland melting ${ }^{18}$. Estimates of geocenter motion derived from GRACE products or satellite laser ranging can be used in these analyses, but the accuracy of the trend in these estimates is difficult to obtain ${ }^{21}$. Finally, the ongoing contribution of vertical land motion from glacial isostatic adjustment (GIA; the isostatic response of the solid Earth to past mass exchange between land ice and oceans) to gravity changes over the oceans is particularly large, with values ranging from -1 to $-2 \mathrm{~mm} / \mathrm{yr}$ (waterequivalent mass change) utilised in recent analyses ${ }^{7,14,15}$.

Altimetry is not a perfect measurement system either. Although comparison with tide gauges shows that an accuracy of $0.4 \mathrm{~mm} / \mathrm{yr}$ should be attainable ${ }^{22,23}$, two of the above analyses ${ }^{14,15}$ give estimates of 3.6 and $2.4 \mathrm{~mm} / \mathrm{yr}$ respectively (both corrected for GIA in the same way). Much of this difference appears to result from the fact that the two fouryear periods of analysis are offset by 6 months, but it should not be forgotten that there is a continual need to check for errors in the various corrections which need to be applied to altimeter data. It is also worth noting that two different tide-gauge based reconstructions of global sea level ${ }^{24,25}$ produce curves (presented in ref. 24) which depart from the altimeter-based record after 1999, although this may reflect the limitations of the tidegauge network rather than the altimetry.

Since the most recent IPCC report, there have been two main advances: 1) correction of the biases in ocean temperature observations ${ }^{9,11}$, which greatly reduces the apparent cooling seen over the last few years ${ }^{10,12}$ as well as reducing the apparent interdecadal variability in steric sea level ${ }^{24}$; and 2) the ability to use three observing systems (altimetry, GRACE, and Argo) to check the degree of closure of the mass flux and steric budget. However, given the short (4 years) and differing time periods for the calculation of trends, it is not surprising that the individual contribution estimates vary between different studies, with central estimates of 0.8 to $2.2 \mathrm{~mm} / \mathrm{yr}$ for mass flux ${ }^{15,16},-0.5$ to 0.8 $\mathrm{mm} / \mathrm{yr}$ for steric ${ }^{14,15}$ and 2.4-3.6 mm/yr from altimetry ${ }^{14,15}$. 
For all these uncertainties, progress is rapid and it is becoming clear that the combination of observing systems is very powerful. But the greatest dividends will come with longer time series as interannual variability becomes less dominant and it becomes possible to isolate the causes of decadal and regional variability.

\section{The $20^{\text {th }}$ Century}

The large spatial variability in sea-level change as well as honest assessment of error sources must also be considered carefully when interpreting older measurements. These necessarily rely on a highly incomplete observing system: the global tide gauge network $^{25}$. From these records (Fig. 2) it is clear that spatial variation is still an important contributor to the measured changes even at the century time scale. Various processes (atmosphere-driven and internal ocean dynamical modes, unmodelled vertical land movement) probably contribute to this variability. In some cases, these processes are likely to produce very localized signals, bringing into question how representative the tide-gauge record is of ocean basin scale averages. More work is needed to resolve the roles of these various processes.

For the globally-integrated budget, the new temperature calibrations cited above improve the balance for the period 1961-2003 (ref. 24), but complete closure contains many uncertainties, including the human influence on land-water storage ${ }^{26}$, and relies on a significant ( $0.2 \mathrm{~mm} / \mathrm{yr})$ unmeasured deep ocean temperature component ${ }^{24}$. It may never be possible to determine the steric contribution to $20^{\text {th }}$ century sea-level change to the same accuracy as can be achieved with the measurement system now in place but it remains important to understand better the magnitudes and error budgets of the various processes that contributed to sea-level change during this period.

Few direct observations of ice mass flux into the oceans exist for the pre-satellite area. One indirect method of estimating the polar mass contributions is to use regional variations in the sea-level response to ice mass change ("fingerprinting"; see Box 1). Initial applications of this method inferred a sea-level trend from Greenland water flux of 0.35 to $0.6 \mathrm{~mm} / \mathrm{yr}^{27,28}$. Unfortunately, steric and dynamical ocean-level changes are significantly larger than the ice-induced signal in most areas ${ }^{29}$ and so should be removed using a combination of ocean models and available data. Such a combination is available for the satellite altimeter period ${ }^{30}$, but for earlier periods this procedure is more speculative. While the improved ocean temperature time series produces less decadal variability in sea level due to the thermosteric process ${ }^{11,24}$, thus reducing the discrepancy between observations and climate models ${ }^{31,32}$, there still remain significant unexplained signals in total sea-level variability. There is a need to assess how much of the dynamical signal can be explained by realistically-forced ocean models, beyond the regional analysis of simplified models ${ }^{33,34}$, and to consider the dynamical as well as the gravitational and isostatic response to melting ice ${ }^{35}$.

An influential paper by Munk ${ }^{36}$ reviewed the status of closure in the sea-level budget for the $20^{\text {th }}$ century and reached a number of conclusions. One of these, based on 
observations and model predictions of changes in Earth rotation, limited the melt contribution from the two ice sheets. The lack of closure led Munk to coin the term "sealevel enigma" since there was no clear solution at that time. The identification of an error in the standard theory of polar motion of the Earth, together with a reassessment of the error bounds on constraints placed by measurements going back to 1979, has shown that geodetic constraints on ice melt over the pre-GRACE period are weaker than previously thought ${ }^{37}$. This result provides a solution to the "enigma" by broadening the uncertainty on the contribution of ice melt to $20^{\text {th }}$ century global mean sea-level rise.

Vertical land motion can introduce highly localised signals to tide-gauge records (tide gauges measure motion of the sea surface relative to the land). One way to reduce the impact of land motion on estimates of global mean sea-level rise in the $20^{\text {th }}$ century is to measure directly the land signal component using the global positioning system (GPS) and remove it to isolate the climate-driven sea-surface variation. A recent application of this method resulted in a decreased standard deviation of the corrected tide gauge rates by $35 \%$ (ref 38). The reduced estimate of global mean sea-level rise $(1.3 \mathrm{~mm} / \mathrm{yr}$ ) offers another solution to the "enigma". GPS rates of land motion are obtained from relatively short times series ( $<10 \mathrm{yr}$ in general) and so this correction procedure might be less applicable in regions where the recent land motion might not represent that for the past 50-100 years (e.g. those affected by frequent and large earthquakes, sediment compaction, large-scale mining and land reclamation).

Rates of sea-level change have varied both spatially and temporally during the $20^{\text {th }}$ century (Fig. 2). Decadal rates of global sea-level rise show large variations throughout the $20^{\text {th }}$ century ${ }^{39}$. A number of recent analyses have studied sea-level accelerations and regional patterns of sea-level change ${ }^{29,40,41}$ and have shown that regional differences, at least partly associated with ocean dynamical response to changes in atmospheric forcing, persist on multi-decadal timescales. Thus, in certain locations, dynamical processes may have contributed significantly to the observed $20^{\text {th }}$ century trend. The influence of these dynamical signals complicates the determination of a global mean acceleration from sealevel records of length > 100 years. For this application, supplementing the tide-gauge data with sea-level data reconstructed from the geological record is highly beneficial. There is strong evidence that global mean sea-level rise has accelerated from a rate of centimetres per century in the past few millennia to decimetres per century in the $20^{\text {th }}$ century ${ }^{42,43}$, but this acceleration does not appear to have been synchronous. Highresolution sea-level records from salt marshes in the North Atlantic ${ }^{44,45}$ and New Zealand ${ }^{46}$ (Fig. 2c) date this acceleration between 1880 and 1920. However, instrumental records ${ }^{41}$ and other proxy records ${ }^{47}$ demonstrate a regional non-synchroneity of sea-level accelerations during the past two centuries. This non-synchroneity likely reflects the spatial variability of sea-level change due to the influence of land-ice changes, oceantemperature change and long-period ocean dynamics.

The past decade has seen the proposal and solution of an attribution problem in explaining the observed global mean sea-level rise for the $20^{\text {th }}$ century. At present, uncertainties in the observed global mean trend as well as in the magnitudes of various contributing processes are large enough to account for any remaining imbalance. An 
important focus for future research is to understand better the observed temporal and spatial variability in sea-level change with respect to the underlying oceanographic and climatic processes.

\section{The Geological Record}

Observations of sea-level change during the past few 100s to 100,000s of years are determined through the use of palaeoecological or morphological information in the geological record (see Table 1). Height and time precision of these records lie in the ranges $10 \mathrm{~s} \mathrm{~m}$ to decimetres and 1000 s to a few years, respectively. Spatial sampling is, in general, poor compared to the distribution of tide gauges and the majority of the data span parts of the Holocene period only (10,000 yr to present), with a distinct paucity of data prior to the last glacial maximum around 25,000 years ago.

During the most recent glacial-interglacial transition (approx. 20-7,000 yr before present) the rates and patterns of sea-level changes were dominated by the mass exchange between ice sheets and oceans and its influence on the solid Earth and gravity field ${ }^{48-50}$. We note that, while there were large ocean temperature changes during the most recent glacial-interglacial transition ${ }^{51}$, the steric effect is likely to have been within data uncertainty in most regions (although this remains to be demonstrated). Fig. 3 shows a selection of data that illustrates some of the spatial and temporal variability of the sealevel response to the ice-ocean mass exchange. At sites distant from major glaciation centres (a-c), sea-level change is dominated by the rate of global ice melt. The observed fall in sea level following the end of major melting ( 7,000 yr before present; Frame b) is due to isostatic processes ${ }^{52}$. A growing number of high resolution records (c) detect an acceleration in sea level around $1850-1900 \mathrm{AD}^{43-45}$. In regions once covered by large ice sheets (e.g. Fennoscandinavia, Canada) crustal uplift dominates the response leading to a monotonic sea-level fall (d). This signal can become relatively complex in adjacent areas (e) due to the interplay between local isostatic and global meltwater signals.

Sea levels in mid-to-low latitudes rose, on average, at a rate of $\sim 1 \mathrm{~m}$ per century (Fig. $3 a$ ), with this rate increasing to $\sim 4 \mathrm{~m}$ per century during periods of exceptionally rapid melting that lasted only a few centuries ${ }^{53,54}$ (Table 1). Of course, these rates must be interpreted carefully when attempting to place a bound on possible rates of future rise as they occurred when there was $70 \%$ more grounded ice on Earth, a significant portion of which was located on continental shelves and therefore inherently unstable. A recent study combining field evidence of ice margin retreat, palaeoclimate observations and modelling has argued that mass loss from the Laurentide ice sheet dominated global melting in the early Holocene and that the rates of low latitude sea-level rise measured during this period (order $1 \mathrm{~m}$ per century) are plausible in the $21^{\text {st }}$ century due to the response of the Greenland ice sheet to predicted warming ${ }^{55}$.

More direct analogues for the response of the present ice sheets to future warming can be found by considering past and present interglacial periods when ice extent was similar to that at present. During the previous interglacial global mean sea level is estimated to have been 4 to $>6 \mathrm{~m}$ higher than present in response to elevated temperatures sustained over a 
few milennia ${ }^{56}$. Studies have indicated that significant volume reductions of both the Greenland $d^{57,58}$ and West Antarctic ice sheets ${ }^{59,60}$ were largely responsible and that rates of sea-level change during this period may have reached values exceeding $1 \mathrm{~m}$ per century $^{6,60}$. During the early to mid-Holocene, the Greenland ice sheet was subjected to temperatures about $2^{\circ} \mathrm{C}$ greater than present values ${ }^{61}$ (compared to $\sim 5^{\circ} \mathrm{C}$ during the previous interglacial ${ }^{58}$ ). The response of the ice sheet to this more modest forcing appears to have been a few decimetres of ice-equivalent sea-level change ${ }^{62,63}$ with rates of melt on the order of a centimetre per century.

During the mid-to-late Holocene, subsequent to the complete disintegration of ice sheets in North America and Eurasia by around 7,000 yr before present, the magnitude and rates of ice melting have been relatively small. Sea-level records from mid-to-low latitude locations (e.g. Fig. 3b), when corrected for isostatic effects, suggest about $3 \mathrm{~m}$ of ice equivalent sea-level change between approximately 7,000 and 3,000 yr before present. There is some disagreement on the timing of the end of ice melting ${ }^{64,65}$, which most likely reflects differences in model parameterisation and data precision. The IPCC ${ }^{65}$ allows for up to $0.4 \mathrm{~m}$ of ice-equivalent sea-level rise since $2 \mathrm{ka}$, but considers it more likely that this value has been zero (within data error bounds) from 2,000 yr until the acceleration to modern rates. This is corroborated by archaeological data from the Mediterranean ${ }^{66}$.

Much of the melt in the mid-to-late Holocene has been attributed to the Antarctic ice sheet ${ }^{67}$. This scenario is supported by evidence for contributions of only a few decimetres from the Greenland ice sheet ${ }^{68-71}$ and small glaciers ${ }^{56}$ during this period and is also consistent with a growing body of data from Antarctica. Das and Alley ${ }^{72}$ documented a change towards a more maritime climate in West Antarctica in the late Holocene which led to considerable ice retreat in Marie Byrd Land ${ }^{73}$ and the Amundsen Sea embayment ${ }^{74}$. Using an ice load model of the Antarctic ice sheet constrained by field evidence of past ice extent and contemporary mass balance measurements, Ivins and James ${ }^{75}$ estimated that the ice sheet contributed $\sim 4 \mathrm{~m}$ to global mean sea-level rise since $\sim 7,000 \mathrm{yr}$, with the majority of this delivered by $\sim 3,000$ yr ago.

Sea-level observations for the mid-to-late Holocene provide constraints on the natural variability of sea-level change immediately preceding the industrial revolution. These data indicate that local rates were generally at the 1-10 cm per century level (see Table 1). For example, high-resolution records based on salt-marsh stratigraphy ${ }^{76}$ and microatolls $\mathrm{s}^{77}$ show that regional short-term fluctuations did not exceed $0.2 \mathrm{~m}$ per century during the middle and late Holocene, including the Medieval Climatic Optimum ${ }^{78,79}$. (We note that these rates are an order of magnitude lower than rates of ice-equivalent sea-level change inferred for some previous interglacial periods using oxygen isotope records ${ }^{5,6}$.) In most studies, the observations have been interpreted in terms of vertical land motion and/or land ice contributions to sea-level change. However, the contributions from steric changes and long-period ocean dynamics may be significant in some areas. For example, during the past 8,000 yr, sea-surface temperatures determined from proxy records indicate changes of magnitude several ${ }^{\circ} \mathrm{C}$ - with some regions experiencing a distinct warming and others a cooling ${ }^{80}$. 
Reconstructions of past sea-level changes demonstrate that the sea-level response to changes in ice sheets has a high degree of spatial and temporal variability over century to millennial time scales. Rates of rise on the order of metres per century sustained over several centuries have occurred in the past during major deglaciation events. Whether such rates can be achieved with the current configuration of ice sheets, as suggested by oxygen-isotope data from the last interglacial ${ }^{6}$, remains an important question for future research.

\section{Towards Improved Predictions of Future Sea-Level Change}

A tightly constrained prediction of sea-level change in the coming decades to millennia requires knowledge of the climate forcing and an ability to calculate accurately the sealevel response to this forcing. The uncertainties in both of these elements are reflected in the spread of global mean sea-level projections offered in the most recent IPCC report ${ }^{2}$ : 0.18-0.59 cm between 1980-1999 and 2090-2099.

Although $70-75 \%$ of the IPCC projected rise is due to ocean temperature change, the influence of ice dynamical changes is identified as a major source of uncertainty. Ongoing and future efforts to understand better the processes that control ice discharge in the large ice sheets and marine terminating glaciers will play a central role in constraining better the land ice contribution to sea level over the $21^{\text {st }}$ century. Sea-level changes reconstructed from the geological record can provide useful constraints on upper limits of ice melt, particularly when combined with additional observational and modelling constraints to isolate the climatic conditions and ice sheet(s) responsible for a given rate of rise ${ }^{55,81}$. Sea-level and climate records for previous interglacial periods are of particular interest given the analogous ice extent and elevated temperatures compared to present (although forcing factors, such as insolation and $\mathrm{CO}_{2}$, may differ). The high rates of sea level change interpreted from oxygen isotope records ${ }^{5,6}$ are certainly troubling and warrant further investigation, particularly through the use of more precise proxy methods.

If spatial variability in sea level were to be included in sea-level projections for the $21^{\text {st }}$ century, the spread in possible values, which would be defined for a specific region or locality, would likely be significantly different than that for the global mean. For example, a recent study concluded on a sea-level rise of 30-80 cm by 2100 in North West Europe $^{82}$. It is possible that in specific areas, the upper bound could be significantly higher due to, for example: land subsidence ${ }^{83}$, ocean dynamics ${ }^{84}$, and gravitational and rotational changes due to ice melting ${ }^{85}$. Even though producing regional projections of sea-level change is considerably more challenging, it must be a focus of future research given the large spatial variability in past changes.

It has become clear from satellite altimetry that steric and dynamic changes have dominated spatial variability in the past few decades and so will most likely continue to do so in the $21^{\text {st }}$ century. While future projections of this component are converging, there remains significant discrepancy at the regional scale ${ }^{2}$. It is critical to maintain the current level of observational control (both satellite and in-situ systems) in order to test 
and calibrate the models over decadal and longer periods. In addition, devising more sophisticated combinations of geodetic and oceanographic data, as well as correctly accounting for temperature sampling errors will result in more rigorous testing of current models.

Advances in our understanding of the causes of past and present sea-level change have been remarkable in the past decade and this progress continues unabated ${ }^{86,87}$. The rich observational data base made available through satellite monitoring has played a central role in the rate of progress. Our understanding of the causes of sea-level changes in the late 1900s and early 2000s will continue to grow as time series lengthen and methods of analysis improve. Observations of the sea-level response prior to the satellite era from both tide gauges and proxy methods provide the length of time series necessary to isolate and interpret the climate component and place the more recent changes in context. Even though current uncertainty on global mean and regional sea-level change for the 21st century is at the metre level, this will no doubt improve in the coming years assuming that observational initiatives are supported.

Correspondence and requests for materials should be addressed to Glenn Milne.

\section{Acknowledgments}

This article stemmed from a meeting hosted by the Geological Society of London in September 2008. We acknowledge support from the Geological Society, the Permanent Service for Mean Sea Level, the Royal Meteorological Society and the Challenger Society. The success of the meeting was, in large part, due to the contributions from the delegates and so we express our gratitude to all who attended and particularly to those who gave presentations. This paper is a contribution to IGCP Project 495 ("Late Quaternary Land-Ocean Interactions: Driving Mechanisms and Coastal Responses”) and to the North and West Europe working group of the INQUA commission on Coastal and Marine Processes. Finally, we thank Kurt Lambeck, Philip Woodworth and two anonymous referees for providing constructive feedback on the original version of this manuscript.

\section{References}

1. Stern, N. The Economics of Climate Change: The Stern Review, Cambridge University Press (2007).

2. Meehl, G.A. et al. in Climate Change 2007: The Physical Science Basis. Contribution of Working Group I to the Fourth Assessment Report of the Intergovernmental Panel on Climate Change (eds Solomon, S. et al.) 747-845 (Cambridge Univ. Press, Cambridge, UK and New York, USA, 2007). 
3. Rahmstorf, S. A semi-empirical approach to projecting future sea-level rise. Science 315, 368-370 (2007).

4. Pfeffer, W. T., Harper, J. T. \& O’Neel, S. Kinematic constraints on glacier contributions to $21^{\text {st }}$ century sea-level rise. Science 321, 1340-1343 doi: 10.1126/science.1159099 (2008).

5. Berger, W.H. Sea level in the late Quaternary: patterns of variation and implications. Int. J. Earth Sci. 97, 1143-1150 doi: 10.1007/s00531-008-0343-y (2008).

6. Rohling, E.J. et al. High rates of sea-level rise during the last interglacial period. Nature Geoscience 1, 38-42 doi: 10.1038/ngeo.2007.28 (2008).

7. Lombard, A. et al. Estimation of steric sea level variations from combined GRACE and Jason-1 data. Earth Planet. Sci. Lett. 254, 194-202 (2007).

8. Lyman, J. M., Willis, J. K. \& Johnson, G. C. Recent cooling in the upper ocean. Geophys. Res. Lett. 33, L18604 doi:10.1029/2006GL027033 (2006).

9. Gouretski, V. \& Koltermann, K. P. How much is the ocean really warming? Geophys. Res. Lett. 34, L01610 doi: 10.1029/2006GL027834 (2007).

10. Willis, J. K., Lyman, J. K., Johnson, G. C. \& Gilson, J. Correction to "Recent cooling of the upper ocean”. Geophys. Res. Lett. 34, L16601 doi: 10.1029/2007GL030323 (2007).

11. Wijffels, S. E. et al. Changing expendable bathythermograph fall-rates and their impact on estimates of thermosteric sea level rise. J. Clim. 21, 5657-5672 doi:10.1175/2008JCLI2290.1 (2008).

12. Willis, J. K., Lyman, J. M., Johnson, C. G. \& Gilson, J. In situ data biases and recent ocean heat content variability. J. Atmos. Oceanic Tech. (in press, doi:10.1175/2008JTECHO608.1) (2008).

13. Dickey, J. O., Marcus, S. L. \& Willis, J. K. Ocean cooling: Constraints from changes in Earth's dynamic oblateness $\left(\mathrm{J}_{2}\right)$ and altimetry. Geophys. Res. Lett. 35, L18608, doi: 10.1029/2008GL035115 (2008).

14. Willis, J. K., Chambers, D. P. \& Nerem, R. S. Assessing the globally-averaged sea level budget on seasonal to interannual timescales. J. Geophys. Res. 113, C06015 doi: 10.1029/2007JC004517 (2008).

15. Leuliette, E. W. \& Miller, L. Closing the sea level rise budget with altimetry, Argo, and GRACE. Geophys. Res. Lett., 36, L04608, doi:10.1029/2008GL036010 (2009).

16. Cazenave, A., Dominh, K., Guinehut, S., Berthier, E., Lovel, W., Ramilien, G., Ablain, M. \& Larnicol, G. Sea level budget over 2003-2008: A reevaluation from GRACE space gravimetry, satellite altimetry and Argo. Global and Planetary Change 65, 83-88 (2009).

17. Palmer, M. D., Haines, K., Tett, S. F. B. \& Ansell, T. J. Isolating the signal of global warming. Geophys. Res. Lett. 34, L23610 doi:10.1029/2007GL031712 (2007).

18. Chambers, D. P., Tamisiea, M. E., Nerem, R. S. \& Ries, J. C. Effects of ice melting on GRACE observations of ocean mass trends. Geophys. Res. Lett. 34, L05610 doi: 10.1029/2006GL029171 (2007).

19. Swenson, S., \& Wahr, J. Post-processing removal of correlated errors in GRACE data. Geophys. Res. Lett. 33, L08402 doi: 10.1029/2005GL025285 (2006).

20. Chambers, D. P. Evaluation of new GRACE time-variable gravity data over the ocean. Geophys. Res. Lett. 33, L17603 doi:10.1029/2006GL027296 (2006). 
21. Swenson, S., Chambers, D. \& Wahr, J. Estimating geocenter variations from a combination of GRACE and ocean model output. J. Geophys. Res. 113, B08410, doi: 10.1029/2007JB005338 (2008).

22. Mitchum, G. T. An improved calibration of satellite altimetric heights using tide gauge sea levels with adjustment for land motion. 23, 145-166 (2000).

23. Leuliette, E. W., Nerem, R. S. \& Mitchum, G. T. Calibration of TOPEX/Poseidon and Jason altimeter data to construct a continuous record of mean sea level change. Marine Geodesy 27, 79-94 (2004).

24. Domingues, C. M. et al. Improved estimates of upper-ocean warming and multidecadal sea-level rise. Nature 453, 1090-1094 doi: 10.1038/nature07080 (2008).

25. Woodworth, P. L. \& Player, R. The Permanent Service for Mean Sea Level: an update to the 21st century. J. of Costal Res. 19, 287-295 (2003).

26. Chao, B. F., Wu,Y. H. \& Li, Y.S. Impact of artificial reservoir water impoundment on global sea level, Science 320, 212-214 doi: 10.1126/science.1154580 (2008).

27. Mitrovica, J. X., Tamisiea, M. E., Davis, J. L. \& Milne, G. A. Recent mass balance of polar ice sheets inferred from patterns of global sea-level change Nature 409, 1026-1029 (2001).

28. Plag, H. Recent relative sea-level trends: an attempt to quantify the forcing factors Phil. Trans. R. Soc. A 364, 821-844 (2006).

29. Douglas, B. C. Concerning evidence for fingerprints of glacial melting. J. Coastal. Res. 24, 218-227 (2008).

30. Wunsch, C., Ponte, R. M. \& Heimbach, P. Decadal trends in sea level patterns: 19932004. J. Climate 20, 5889-5911 doi: 10.1175/2007JCLI1840.1 (2007).

31. Gregory, J. M., Banks, H. T, Stott, P. A., Lowe, J. A. \& Palmer, M. D. Simulated and observed decadal variability in ocean heat content. Geophys. Res. Lett. 31, L15312 doi:10.1029/2004GL02058 (2004).

32. Achuta Rao, K. M. et al. Simulated and observed variability in ocean temperature and heat content. Proc. Natl. Acad. Sci. USA 204, 10768-10773 (2007).

33. Marcos, M. \& Tsimplis, M. N. Forcing of coastal sea level rise patterns in the North Atlantic and the Mediterranean Sea. Geophys. Res. Lett. 34, L01604 doi:10.1029/2007GL030641 (2007).

34. Cabanes, C., Huck, T., \& de Verdiere, A. C. Contributions of wind forcing and surface heating to interannual sea level variations in the Atlantic Ocean. J. Phys. Oceanogr. 36, 1739-1750 (2006).

35. Stammer, D. Response of the global ocean to Greenland and Antarctic ice melting. $J$. Geophys. Res. 113, C06022 doi:10.1029/2006JC004079 (2008).

36. Munk, W. Twentieth century sea level: an enigma. Proc. Natl. Acad. Sci. 99, 65506555 (2002).

37. Mitrovica, J. X., Wahr, J., Matsuyama, I., Paulson, A. \& Tamisiea, M. E. Reanalysis of ancient eclipse, astronomic and geodetic data: A possible route to solving the enigma of global sea-level rise. Earth. Planet. Sci. Lett. 243, 390-399 (2006).

38. Wöppelmann, G., Miguez, B. M., Bouin, M. \& Altamimi, Z. Geocentric sea-level trend estimates from GPS analyses at relevant tide gauges world-wide Glob. Planet. Change 57, 396-406 (2007).

39. Holgate, S. On the decadal rates of sea level change during the twentieth century. Geophys. Res. Lett. 34, L01602 doi:10.1029/2006GL019626 (2007). 
40. Miller, L. \& Douglas, B. C. Gyre-scale atmospheric pressure variations and their relation to $19^{\text {th }}$ and $20^{\text {th }}$ century sea level rise. Geophys. Res. Lett. 34, L16602 doi:10.1029/2007GL030862 (2007).

41. Woodworth, P. L. et al. Evidence for the accelerations of sea level on multi-decade and century timescales. Int. J. Climat. (in press, doi:10.1002/joc.1771) (2008).

42. Shennan, I. \& Horton, B.P. Holocene land- and sea-level changes in Great Britain. J. Quat. Sci. 17, 511-526 (2002).

43. Gehrels, W. R., Milne, G. A., Kirby, J. R., Patterson, R. T. \& Belknap, D. F. Late Holocene sea-level changes and isostatic crustal movements in Atlantic Canada. Quat. Int. 120, 79-89 (2004).

44. Donnelly, J. P., Cleary, P., Newby, P. \& Ettinger, R. Coupling instrumental and geological records of sea-level change: Evidence from southern New England of an increase in the rate of sea-level rise in the late $19^{\text {th }}$ century. Geophys. Res. Lett. 31, L05203 doi:10.1029/2003GL018933 (2004).

45. Gehrels, W. R. et al. Onset of recent rapid sea-level rise in the western Atlantic Ocean. Quat. Sci. Rev. 24, 2083-2100 (2005).

46. Gehrels, W. R., Hayward, B. W., Newnham, R. M. \& Southall, K. E. A $20^{\text {th }}$ century sea-level acceleration in New Zealand. Geophys. Res. Lett. 35, L02717 doi 10.1029/2007GL032632 (2008).

47. Gehrels, W. R. et al. Rapid sea-level rise in the North Atlantic Ocean since the first half of the $19^{\text {th }}$ century. The Holocene 16, 948-964 (2006).

48. Clark, J. A., Farrell, W. E. \& Peltier, W. R. Global changes in postglacial sea level: a numerical calculation. Quat. Res. 9, 265-287 (1978).

49. Peltier, W. R. Postglacial variations in the level of the sea: implications for climate dynamics and solid-earth geophysics. Rev. Geophys. 36, 603-689 (1998).

50. Lambeck, K. \& Chappell, J. Sea level change through the last glacial cycle. Science 292, 679-686 (2001).

51. CLIMAP Members. Seasonal Reconstruction of the Earth's Surface at the Last Glacial Maximum. Map and Chart Series MC-36, Boulder Colorado, Geological Society of America (1981).

52. Mitrovica, J. X. \& Milne, G. A. On the origin of late Holocene sea-level highstands within equatorial ocean basins. Quat. Sci. Rev. 21, 2179-2190 (2002).

53. Bard, E., Hamelin, B., Fairbanks, R. G. \& Zindler, A. Calibration of the 14C timescale over the past 30,000 years using mass spectrometric U-Th ages from Barbados corals. Nature 345, 405-410 (1990).

54. Hanebuth, T., Stategger, K. \& Grootes, P. Rapid flooding of the Sunda Shelf: A lateglacial sea-level record. Science 288, 1033-1035 (2000).

55. Carlson, A. E. et al. Rapid early Holocene deglaciation of the Laurentide ice sheet. Nature Geoscience 1, 620-624 doi: 10.1038/ngeo285 (2008).

56. Jansen, E. et al. in Climate Change 2007: Th e Physical Science Basis. Contribution of Working Group I to the Fourth Assessment Report of the Intergovernmental Panel on Climate Change (eds Solomon, S. et al.) 433-497 (Cambridge Univ. Press, Cambridge, UK and New York, USA, 2007).

57. Cuffey, K. M. \& Marshall, S. J. Substantial contribution to sea-level rise during the last interglacial from the Greenland ice sheet. Nature 404, 591-594 (2000). 
58. Otto-Bliesner, B. L. et al. Simulating Arctic climate warmth and icefield retreat in the last interglaciation. Science 311, 1751-1753 doi:10.1126/science.1120808 (2006).

59. Sherer, R. P. et al. Pleistocene collapse of the West Antarctic ice sheet. Science 281, 82-85 doi:10.1126/science.281.5373.82 (1998).

60. Overpeck, J. T. et al. Paleoclimatic evidence for future ice-sheet instability and rapid sea-level rise. Science 311, 1747-1750 doi:10.1126/science.1115159 (2006).

61. Dahl Jensen, D. et al. Past temperatures directly from the Greenland Ice Sheet. Science 282, 268-271 (1998).

62. Tarasov, L. \& Peltier, W.R. Greenland glacial history and local geodynamic consequences. Geophys. J. Int. 150, 198-229 (2002).

63. Simpson, M. J. R., Milne G.A., Huybrechts, P. \& Long. A. J. Calibrating a glaciological model of the Greenland ice sheet from the last glacial maximum to present-day using field observations of relative sea level and ice extent. Quat. Sci. Rev. (in press) (2008).

64. Gehrels, W. R. Sea-level changes since the Last Glacial Maximum: An appraisal of the IPCC Fourth Assessment Report. J. Quat. Sci. (in press) (2008).

65. Bindoff, N. L. et al. in Climate Change 2007: The Physical Science Basis. Contribution of Working Group I to the Fourth Assessment Report of the Intergovernmental Panel on Climate Change (eds Solomon, S. et al.) 385-432 (Cambridge Univ. Press, Cambridge, UK and New York, USA, 2007).

66. Lambeck, K., Anzidei, M., Antonioli, F., Benini, A. \& Esposito, A. Sea level in Roman time in the Central Mediterranean and implications for recent change. Earth Planet. Sci. Lett. 224, 563-575 (2004).

67. Nakada, M. \& Lambeck, K. The melting history of the late Pleistocene Antarctic ice sheet. Nature 33, 36-40 (1988).

68. Long, A. J., Roberts, D. H. \& Rasch, M. New observations on the relative sea level and deglacial history of Greenland from Innaarsuit, Disko Bugt. Quat. Res. 60, 162171 (2003).

69. Mikkelsen, M., Kuijpers, A. \& Arneborg, J. The Norse in Greenland and late Holocene sea-level change, Polar Record 44, 45-50 (2008).

70. Sparrenbom, C. J., Bennike, O., Björck, S. and Lambeck, K. Holocene relative sealevel changes in the Qaqortoq area, southern Greenland. Boreas 35, 171-187 (2006).

71. Weidick, A., Kelly, M. and Bennike, O. Late Quaternary development of the southern sector of the Greenland Ice Sheet, with particular reference to the Qassimiut lobe, Boreas 33, 284-299 (2004).

72. Das, S. B. \& Alley, R. B. Rise in frequency of surface melting at Siple Dome through the Holocene: Evidence for increasing marine influence on the climate of West Antarctica, Journal of Geophysical Research 113, D02112 doi:10.1029/2007JD008790 (2008).

73. Stone, J. O. et al. Holocene deglaciation of Marie Byrd Land, West Antarctica. Science 299, 99-102 (2003).

74. Johnson, J. S., Bentley, M. J. \& Gohl, K. First exposure ages from the Amundsen Sea embayment, West Antarctica: The late Quaternary context for recent thinning of Pine Island, Smith, and Pope Glaciers. Geology 36, 223-226 (2008).

75. Ivins, E. R. \& James, T. S. Antarctic glacial isostatic adjustment: a new assessment. Ant. Sci. 17, 541-553 (2005). 
76. Gehrels, W. R. Middle and late Holocene sea-level changes in eastern Maine reconstructed from foraminiferal saltmarsh stratigraphy and AMS 14C dates on basal peat. Quat. Res. 52, 350-359 (1999).

77. Goodwin, I. D. \& Harvey, N. Subtropical sea-level history from coral microatolls in the Southern Cook Islands, since 300 AD. Marine Geology 253, 14-25 (2008).

78. van de Plassche, O., van der Borg, K. \& de Jong, A. F. M. Sea level-climate correlation during the past 1400 yr. Geology 26, 319-322 (1998).

79. Gehrels, W. R. et al. Late Holocene sea-level changes and isostasy in western Denmark. Quat. Res. 66, 288-302 (2006).

80. Brovkin, V., Kim, J.-H., Hofmann, M. and Schneider, R. A lowering effect of reconstructed Holocene changes in sea surface temperatures on the atmospheric CO2 concentration. Global Biogeochemical Cycles 22, doi:10.1029/2006GB002885 (2008).

81. Clark, P.U., Mitrovica, J.X., Milne, G.A. \& Tamisiea, M.E. Sea-level fingerprinting as a direct test for the source of global meltwater pulse IA. Science 295, 2438-2441 (2002).

82. Katsman, C. A., Hazeleger, W., Drijfhout, S. S., van Oldenborgh, G. J. \& Burgers, G. Climate scenarios of sea level rise for the northeast Atlantic Ocean: a study including the effects of ocean dynamics and gravity changes induced by ice melt. Climatic Change 91, 351-374 doi:10.1007/s10584-008-9442-9 (2008).

83. Tornqvist, T E., Bick, S. J., van der Borg, K. \& de Jong, A. F. M. How stable is the Mississippi delta? Geology 34, 697-700 doi:10.1130/G22624.1 (2006).

84. Yin, J., Schlesinger, M. E. \& Stouffer, R. J. Model projections of rapid sea-level rise on the northeast coast of the United States. Nature Geoscience, doi:10.1038/ngeo462 (2009).

85. Mitrovica, J. X., Gomez, N. \& Clark, P. U. The sea-level fingerprint of West Antarctic collapse. Science 323, 753 doi:10.1126/science.1166510 (2009).

86. Church, J. A. et al. Understanding global sea levels : past, present and future. Sustain. Sci. 3, 9-22 doi: 10.1007/s11625-008-0042-4 (2008).

87. Cazenave, A., Lombard, A. \& Llovel, W. Present-day sea level rise: A synthesis. C. R. Geoscience 340, 761-770 doi:10.1016/j.crte.2008.07.0082008 (2008).

88. Waelbroeck, C. et al. Sea-level and deep water temperature changes derived from benthic foraminifera isotopic records, Quat. Sci. Rev. 21, 295-305 (2002).

89. Siddall, M. et al. Sea-level fluctuations during the last glacial cycle. Nature 423, 853858 (2003).

90. Arz, H. W., Lamy, F., Ganopolsky, A., Nowaczyk, N. and Pätzold, J. Dominant Northern Hemisphere climate control over millennial-scale glacial sea-level variability. Quat. Sci. Rev. 26, 312-323 (2007).

91. Fairbanks, R. G. A 17000-year glacio-eustatic sea level record: influence of glacial melting rates on the Younger Dryas event and deep-ocean circulation. Nature 342, 637-642 (1989).

92. Yokoyama, Y., Lambeck, K., de Deckker, P., Johnston, P. and Fifield, K. Timing of the Last Glacial Maximum from observed sea-level minima. Nature 406, 713-716 (2000). 
93. Shennan, I., Hamilton, S., Hillier, C., Woodroffe, S. A 16 000-year record of nearfield relative sea-level changes, northwest Scotland, United Kingdom. Quat. Int. 133134, 95-106 (2005).

94. Laborel, J. and Laborel-Deguen, F. Biological indicators of Holocene sea-level and climatic variations on rocky coasts of tropical and subtropical regions. Quat. Int. 31, 53-60 (1996).

95. Jevrejeva, S., Grinsted, A., Moore, J. C. \& Holgate, S. J. Nonlinear trends and multiyear cycles in sea level records, J. Geophys. Res. 111, C09012 doi:10.1029/2005JC003229 (2006).

96. Woodroffe, S. A. Reconstructing sea-level changes in North Queensland, Australia, using a foraminifera-based transfer function. The Holocene, in review (2008).

97. Lambeck, K., Smither, C. \& Johnston, P. Sea-level change, glacial rebound and mantle viscosity for northern Europe. Geophys. J. Int. 134, 102-144 (1998).

98. Farrell W. \& Clark, J. T. Farrell, W.E., Clark, J.T. On postglacial sea level. Geophys. J. Royal Astro. Soc. 46, 647-667 (1976).

99. Tamisiea, M. E., Mitrovica, J. X., Davis, J. L. \& Milne, G. A. Long wavelength sea level and solid surface perturbations driven by polar ice mass variations: fingerprinting Greenland and Antarctic ice sheet flux. Space Science Reviews 108, 81-93 (2003).

100. Berge-Nguyen et al. Reconstruction of past decades sea level using thermosteric sea level, tide gauge, satellite altimetry and ocean reanalysis data. Global Planet. Change 62, 1-13 doi: 10.1016/j.gloplacha.2007.11.007 (2008).

\section{$\underline{\text { Table and Figure Captions }}$}

\section{$\underline{\text { Table } 1}$}

Methods of sea-level reconstruction over various time scales and the time and height precision associated with each. The maximum rate of sea-level rise is given for each time period and reconstruction method (note that rates have been corrected for land motion). The * symbol indicates uncertainties that are tidal range dependent. Some methods quantify the error on inferred past sea levels by analyzing the distribution of flora and fauna within the tidal zone and so the estimated uncertainty is less in areas with smaller tidal range.

\section{Figure 1}

Mean rate of sea-surface height change during the period October 1992 to May 2007 determined from satellite altimetry measurements. Measurements were corrected for the inverted barometer effect. The large spatial variability reflects the dominance of dynamical ocean processes over this period. The measurement error at a given point is difficult to assess, but probably less than $2 \mathrm{~mm} / \mathrm{yr}$. Variations also occur on many different time scales, so that a linear trend is not a statistically significant fit to the time series at most places, the trend is merely indicative of the kind of variability to be found. 


\section{Figure 2}

Sea-level curves derived from tide gauge data using the 'virtual station' method ${ }^{95}$ The robustness of each of the regional estimates varies greatly both spatially due the geographic distribution of the stations, with an inherent northern hemisphere bias present in the network, and temporarily due to the changing number of stations, with a very limited number of records spanning the entire $20^{\text {th }}$ century. (Adapted from ref. 41.)

\section{$\underline{\text { Figure } 3}$}

Sea levels reconstructed from the geological record at five localities. (a) Barbados ${ }^{53,91}$; (b) Cleveland Bay, Australia ${ }^{96}$; (c) Pounawea, New Zealand ${ }^{46}$; (d) Angerman River, Sweden $^{97}$; (e) Arisaig, Scotland ${ }^{93}$. These data were chosen to illustrate the spatial and temporal variation in sea-level change during and following the most recent glacialinterglacial transition and the typical time and height precision obtained using commonly used reconstruction methods. Note that the data in (D) are obtained from more than one type of sea-level indicator. Note, also, that, at most sites, the data span different time periods.

\section{Box 1: Processes affecting sea level}

Sea level is measured in one of two ways: relative to the ocean floor (known as 'relative sea level') or relative to the Earth's centre of mass (know as 'absolute sea level').

Satellite altimetry is the only method that provides a measure of absolute sea level. Both relative and absolute sea level are affected by a wide variety of processes (a). Note that absolute sea level is affected indirectly by deformation of the solid Earth due to the corresponding changes to the gravity field and volume of the global ocean basin. All of the processes depicted in (a) result in a spatially variable sea-level response.

Two climate-related processes that will play central roles in governing sea-level changes over the coming decades to centuries are land ice melting (mass contribution) and ocean water density change due to temperature and salinity changes (steric contribution). The spatial variability associated with these processes is depicted, respectively, in (b) and (c).

It is generally assumed than when land ice melts, the associated sea-level rise is globally uniform and proportional to the volume of ice loss. For example, it is often stated that the Greenland ice sheet holds about $7 \mathrm{~m}$ of global sea-level rise. In reality, the situation is more complex due to the isostatic deformation of the solid Earth along with gravitational and rotational changes driven by the ice-ocean mass exchange ${ }^{27,85,98}$. Frame (b) shows model predictions of the change in global sea-level if the Greenland (top) or West Antarctic (bottom) ice sheets were to lose mass at $1 \mathrm{~mm} / \mathrm{yr}(10 \mathrm{~cm} /$ century) of global mean sea-level equivalent. The predicted response departs significantly from the mean with a reduced rise and even fall in areas close to the ablating ice mass and an amplified rise in areas far-removed from the melt source ${ }^{99}$. 
Ocean temperature and salinity changes have also been regionally variable in the past and estimates of the resulting sea-level change reflect this variability. Frame (c) shows the mean rates of sea-level change over the period 1950-2003 estimated from observations of ocean temperature (taken from ref 100). 
a

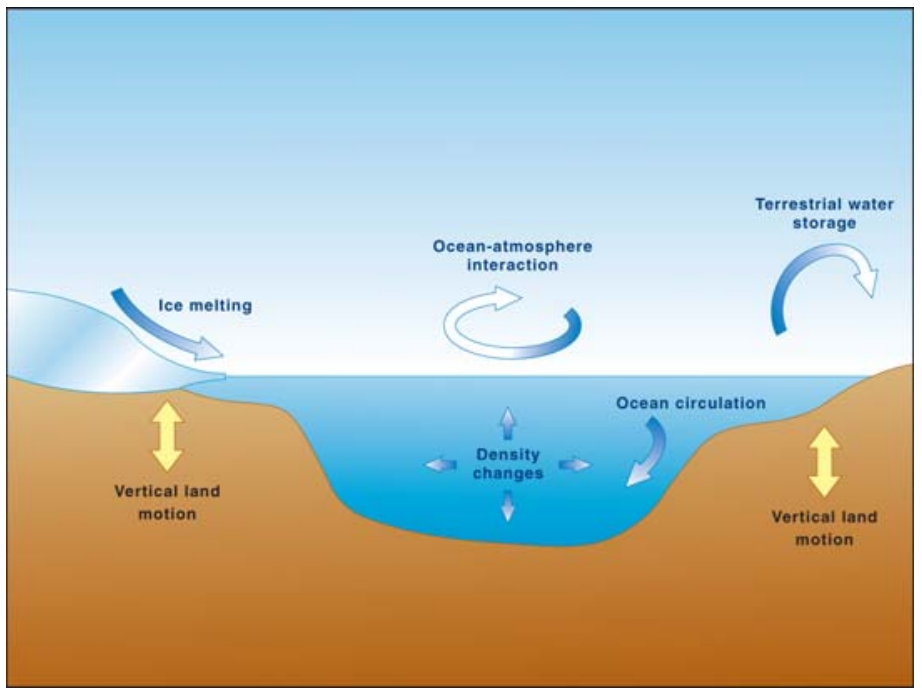

C
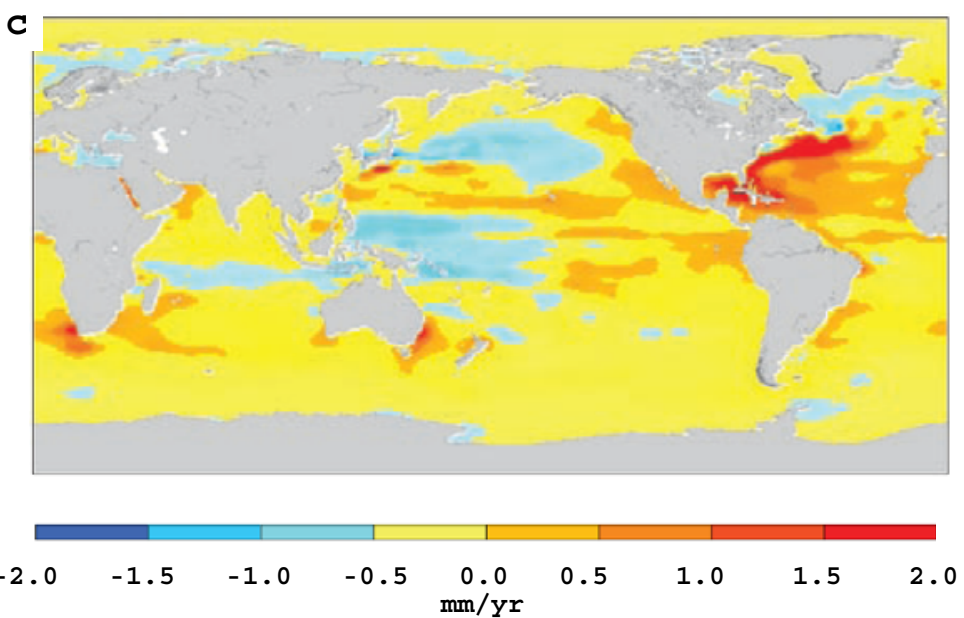

b
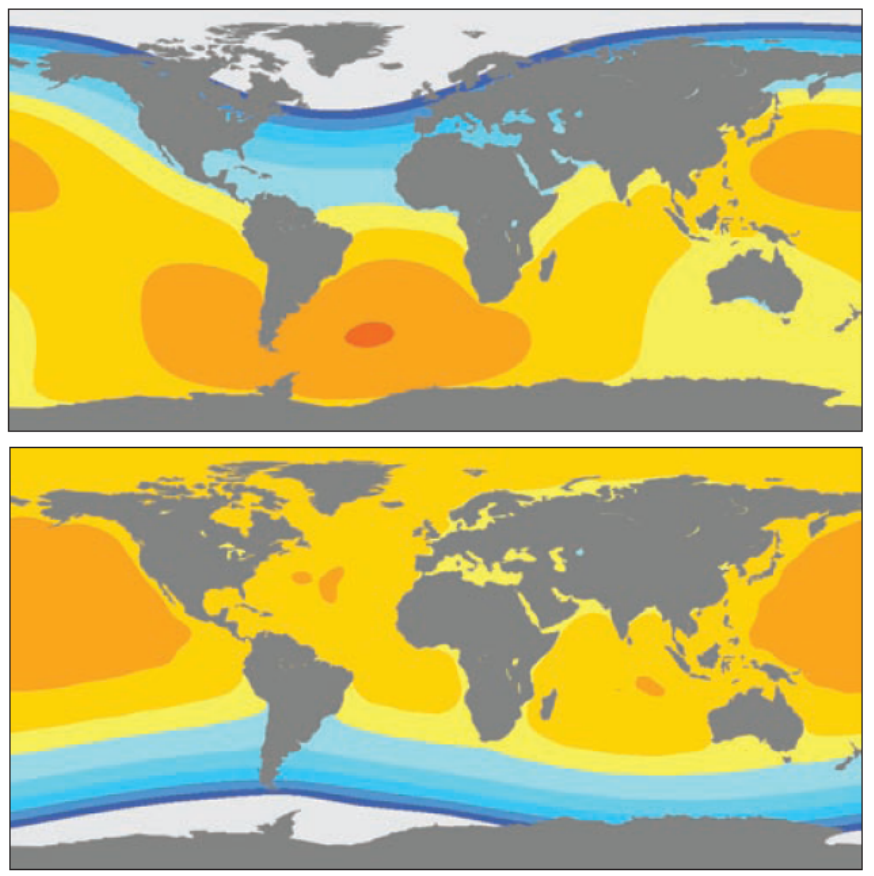

$\begin{array}{llllllllll}0.0 & 0.2 & 0.4 & 0.6 & \begin{array}{l}0.8 \\ \mathrm{~mm} / \mathrm{yr}\end{array} & 1.0 & 1.1 & 1.2 & 1.3 & 1.4\end{array}$ 


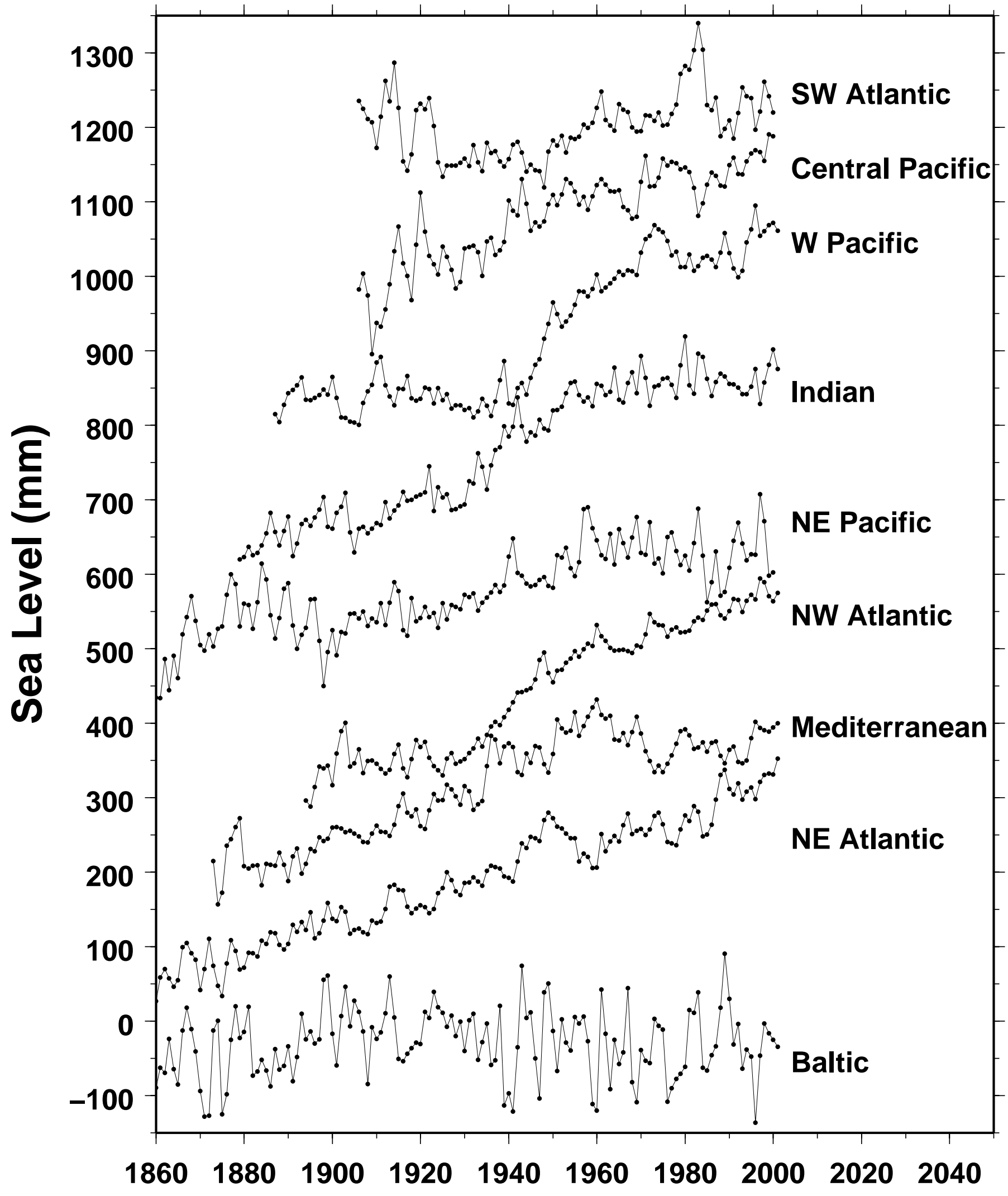




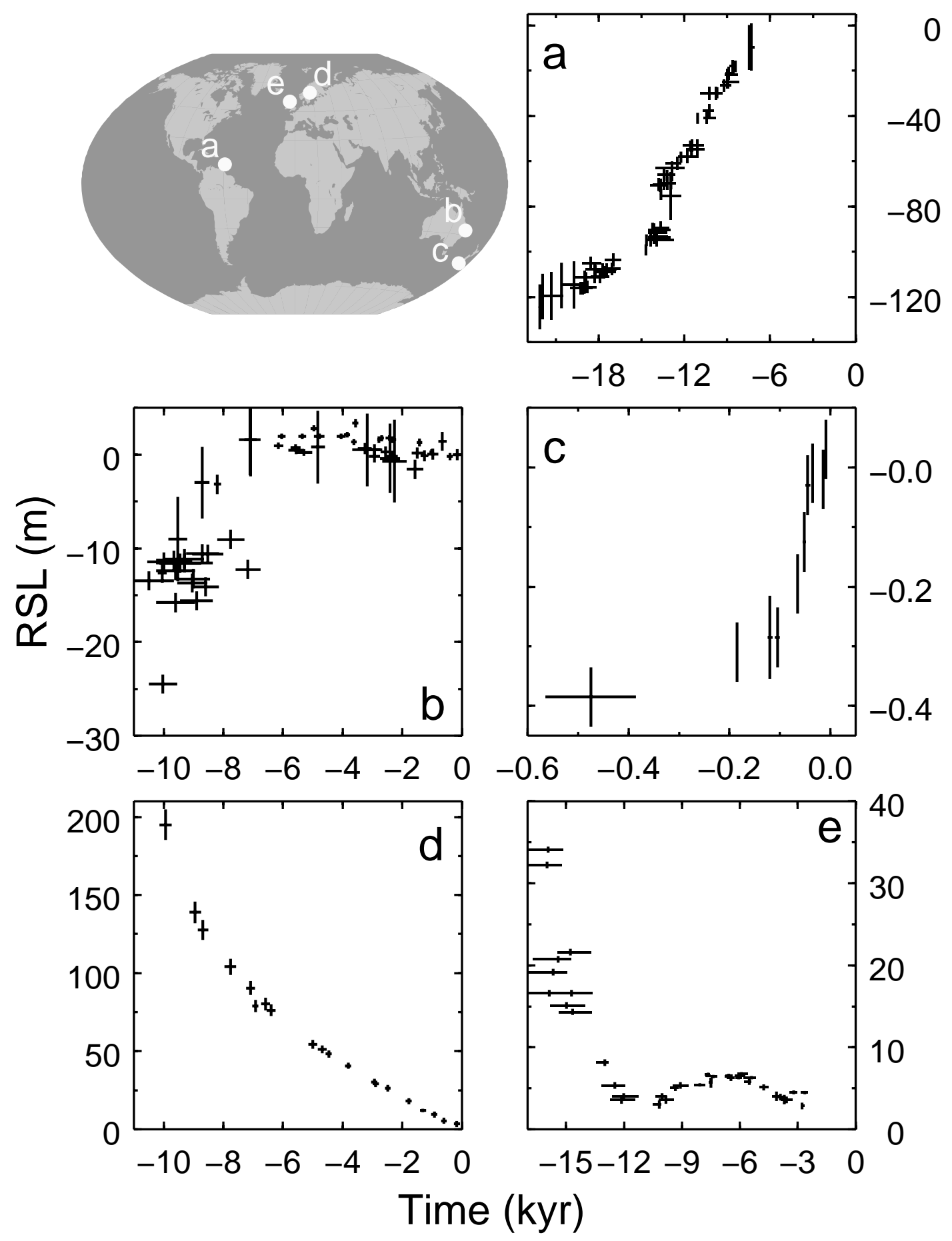




\begin{tabular}{|c|c|c|c|c|c|c|}
\hline $\begin{array}{l}\text { Time } \\
\text { period }\end{array}$ & $\begin{array}{l}\text { Sea-level } \\
\text { indicator }\end{array}$ & Chronology & $\begin{array}{l}\text { Max. } \\
\text { resolution } \\
\text { (yr) }\end{array}$ & $\begin{array}{l}\text { Estimated } \\
\text { vertical } \\
\text { precision } \\
( \pm \mathrm{m})\end{array}$ & $\begin{array}{l}\text { Max. rate } \\
\text { (m/century) }\end{array}$ & $\begin{array}{l}\text { Example } \\
\text { studies }\end{array}$ \\
\hline $\begin{array}{l}0-470 \\
\text { ka }\end{array}$ & $\begin{array}{l}\text { Oxygen } \\
\text { isotopes }\end{array}$ & $\begin{array}{l}\mathrm{AMS}^{14} \mathrm{C}, \\
\text { palaeomagnetism, } \\
\text { tuning }\end{array}$ & 200 & 12 & 2.5 & $6,88-90$ \\
\hline $0-30 \mathrm{ka}$ & Corals & $\mathrm{U} / \mathrm{Th}$ & 400 & 5 & 4 & 53,91 \\
\hline $0-20 \mathrm{ka}$ & $\begin{array}{l}\text { Sediment } \\
\text { facies, } \\
\text { microfossils }\end{array}$ & $\mathrm{AMS}^{14} \mathrm{C}$ & 200 & 3 & 4 & 54,92 \\
\hline $0-16 \mathrm{ka}$ & $\begin{array}{l}\text { Isolation } \\
\text { basin } \\
\text { stratigraphy }\end{array}$ & $\mathrm{AMS}^{14} \mathrm{C}$ & 200 & $0.2-1.0^{*}$ & n.a. & 93 \\
\hline $0-10 \mathrm{ka}$ & Basal peat & $\mathrm{AMS}^{14} \mathrm{C}$ & 200 & $0.2-0.5^{\star}$ & 0.2 & 76 \\
\hline $0-7 \mathrm{ka}$ & Microatolls & ${ }^{14} \mathrm{C}$ & 200 & $0.1-0.2^{*}$ & 0.2 & 77 \\
\hline 0-7 ka & $\begin{array}{l}\text { Biological } \\
\text { indicators on } \\
\text { rocky coasts }\end{array}$ & ${ }^{14} \mathrm{C}$ & 200 & $0.05-0.5^{\star}$ & 0.1 & 94 \\
\hline $0-2 \mathrm{ka}$ & Archaeology & $\begin{array}{l}\text { Historical } \\
\text { documentation }\end{array}$ & 100 & $0.1-0.5^{\star}$ & 0.1 & 66 \\
\hline $\begin{array}{l}0-0.5 \\
\mathrm{ka}\end{array}$ & $\begin{array}{l}\text { Salt-marsh } \\
\text { microfossils }\end{array}$ & $\begin{array}{l}\mathrm{AMS}{ }^{14} \mathrm{C},{ }^{210} \mathrm{~Pb}, \\
{ }^{137} \mathrm{Cs}, \mathrm{Pb} \text { isotopes, } \\
\text { pollen, } \\
\text { chemostratigraphy }\end{array}$ & 20 & $0.05-0.3^{*}$ & 0.2 & 46 \\
\hline
\end{tabular}

